\title{
Pengaruh Model Contextual Teaching and Learning (CTL) Berbantuan Media Permainan Ular Tangga Terhadap Penguasaan Konsep Fisika Siswa
}

\author{
Arin Wildani*, Agus Budiyono, Zaitun \\ Program Studi Pendidikan Fisika, Universitas Islam Madura \\ *Email: arinwildani@gmail.com
}

Received: 12 Agustus 2021; Accepted: 13 September 2021;

Published: 23 Oktober 2021

DOI: http://dx.doi.org/10.29303/jpft.v7i2.2864

\begin{abstract}
This research was conducted with the aim of knowing the effect of applying the CTL learning model assisted by snakes and ladders media on students' conceptual mastery in pesantren-based schools. This research is a quasi-experimental research with research design using pretest-posttest control group design. The population in this study were all students of a pesantren-based school in Pamekasan. while the sample consists of two groups, namely the experimental class and the control class with the sampling technique using random sampling technique. The sample of the experimental class and control class consisted of 40 students. The experimental class was given the CTL model learning treatment with snakes and ladders media while the control class only applied the CTL model. The instrument used in this research is the student's concept mastery test instrument in the form of multiple-choice questions. Data was collected by means of tests and filling out questionnaires. Data analysis was carried out by using the Independent Sample T Test. The results showed that tcount > ttable with a significance of 0.000 or a significance of $<0.05$, which means that the snake-and-ladderassisted model has a significant effect on students' conceptual mastery.
\end{abstract}

Keywords: CTL model; concept mastery; snake and ladder

\section{PENDAHULUAN}

Seorang siswa dikatakan telah memahami konsep jika memiliki kemampuan memahami makna dari materi yang sedang dipelajari baik secara ilmiah ataupun teori dan juga bisa menerapkannya dalam kehidupan sehari-hari (Silaban, 2014). Hal tersebut berlaku pada semua mata pelajaran termasuk mapel fisika. seorang siswa dikatakan telah menguasai konsep fisika jika siswa bisa memahami konsepkonsep fisika secara ilmiah, teori maupun mampu menerapkannya dalam kehidupan seharihari serta mampu membawa konsep tersebut untuk permasalahan permasalahannya yang lain. Penguasaan konsep siswa ditandai oleh skor pencapaian siswa dalam proses pembelajaran yang diukur berdasarkan jenjang taksonomi Bloom (Husein et al., 2017).

Penguasaan konsep bukan hanya sekedar menghafal saja, secara khusus pada konsep fisika harusnya bukanlah hanya sekedar rumus kemudian digunakan menyelesaikan soal soal, melainkan konsep itu harus dipahami sehingga dapat digunakan untuk memecahkan masalah yang dihadapi dengan bantuan rumus rumus yang ada (Kamariyah \& Budiyono, 2020). Siswa yang telah memahami konsep pasti dapat menjelaskan suatu informasi dengan kalimat sendiri dan tidak memerlukan bantuan buku catatan untuk dibaca. Siswa dapat menjelasakan dengan lancar menggunakan kalimatnya sendiri (Lutvaidah, 2016). Siswa dikatakan telah menguasai konsep apabila setelah proses pembelajaran mampu mengingat, memahami apa yang dikerjakan, menggetahui apa yang sedang disampaikan, menyampaikan uraian yang lebih detail dengan mengggunakan kata-kata sendiri, bisa memecahkan masalah yang sedag dihadapi, serta mampu mengaplikasikannya dalam kehidupan sehari-hari di linkungannya 
mupun di lingkungan masyarakat (Puryadi et al., 2018).

Penguasaan konsep siswa merupakan aspek penting yang menjadi perhatian utama dari guru. Penguasaan konsep siswa dipengaruhi oleh berbagai faktor, salahsatunya yaitu model pembelajaran yang digunakan dalam proses pembelajaran. sehingga diperlukan inovasi penggunaan model pembelajaran yang menyenangkan bagi siswa dan membuat siswa tertarik mengikuti proses pembelajaran (Sumarni et al., 2020). Selain itu juga dibutuhkan model pembelajaran yang tidak hanya menekankan guru sebagai sumber informasi melainkan pembelajaran yang belajar dari kejadian di lingkungan sekitar siswa. Salahsatu model pembelajaran yang terbukti dapat meningkatkan penguasaan konsep siswa yaitu model Contextual Teaching Learning (CTL). Model ini menggunakan pendekatan kontesktual atau peristiwa di kehidupan nyata dengan materi yang sedang di pelajari (Suprianto et al., 2016). Model pembelajaran CTL bisa memberikan suasana yang menarik dalam proses pembelajaran. kelebihan model pembelajaran CTL yaitu pembelajaran berpusat pada siswa, siswa lebih aktif di kelas, guru menjadi fasilitator dan tetap dapat memantau anak didik (Dewi \& Primayana, 2019).

Karakteristik proses pembelajaran yang menggunakan CTL, yaitu: 1) Proses pembelajaran dalam CTL merupakan proses pemahaman pengetahuan yang sudah dipelajari siswa menjadi pengetahuan yang utuh yang satu sama lain memiliki keterkaitan. 2) Pembelajaran untuk memperoleh dan menambah pengetahuan baru yang diperoleh dengan cara deduktif 3) pembelajaran dalam rangka pemahaman pengetahuan sehingga siswa tidak hanya hafalan teori 4) Pembelajaran dalam rangka mempraktikan pengetahuan dan pengalamanyang didapat siswa 5)
Pembelajaran untuk pengembangan pengetahuan (Fadillah et al., 2017).

Penerapan model CTL dalam proses pembelajaran terbukti efektif dalam meningkatkan hasil belajar siswa dalam berbagai mata pelajaran seperti fisika, biologi, matematika (Permatasari et al., 2013; Rahmawati et al., 2019; Suprianto et al., 2016). Model CTL juga mampu meningkatkan kompetensi yang dibutuhkan siswa untuk pembelajaran abad 21 seperti keterampilan berfikir kritis, keterampilan pemecahan masalah dan keterampilan komunikasi (Mauke et al., 2013; Ratnasari \& Saefudin, 2018). Model CTL juga terbukti dapat meningkatkan motivasi siswa di kelas (Hapizoh et al., 2020; Yulia \& Ningsih, 2018). Begitu juga terhadap penguasaan konsep, model ini terbukti dapat meningkatkan penguasaan konsep siswa (Huda et al., 2019).

Selain inovasi model pembelajaran yang akan digunakan, guru juga dapat melakukan inovasi dalam penggunaan media pembelajaran untuk mempermudah atau membuat proses pembelajaran lebih menarik. Salahsatu media yang dapat digunakan yaitu media permainan ular tangga. Media ular tangga merupakan permainan untuk anak-anak yang digambar dalam bentuk ular dan tangga yang menghubungkan beberapa kotak kecil. Permainan ini dapat di mainkan oleh 2 orang atau lebih (Nugroho et al., 2013). Media ular tangga ini dapat dijadikan sebagai media pembelajaran yang menyenangkan bagi siswa. Siswa akan tertarik mengikuti proses pembelajaran khususnya pembelajaran fisika (Firman \& Maisyarah, 2019).

Yang terjadi di lapangan banyak siswa yang merasa fisika itu sulit dan membosankan. Fisika dikenal sebagai mapel yang hanya berisi tentang rumus rumus. Kondisi tersebut membuat siswa malas untuk belajar fisika dan berdampak pada rendahnya 
penguasaan konsep fisika dari siswa. Untuk mengatasi kondisi tersebut maka diperlukan inovasi pembelajaran yang menarik. Oleh karena itu pada penelitian ini diterapkan model pembelajaran CTL dengan berbantuan media ular tangga untuk mengetahui pengaruh penerapan model pembelajaran CTL dengan bantuan media permainan ular tangga terhadap penguasaan konsep fisika siswa. Kolaborasi penggunaan model CTL dengan bantuan media ular tangga belum pernah digunakan sebelumnya khususnya untuk mata pelajaran fisika.

\section{METODE PENELITIAN}

Penelitian ini termasuk penelitian eksperimen semu dengan desain penelitian menggunakan pretest-postest control group design. Populasi pada penelitian ini yaitu seluruh siswa MA Miftahul Ulum Bettet Pamekasan sedangkan sampel terdiri dari dua kelompok yaitu kelas XA sebagai kelas eksperimen dan kelas XC sebagai kelas kontrol dengan teknik pengambilan sampel menggunakan teknik random sampling. Sampel kelas eksperimen dan kelas kontrol masing masing terdiri dari 40 siswa. Pada kelas eksperimen diberikan perlakuan pembelajaran model CTL berbantuan media ular tangga sedangkan kelas kontrol hanya penerapan model CTL.. Kedua kelompok sampel ini sama2 diberikan pretest sebelum perlakukan dan posttest setelah perlakuan. Instrument yang digunakan pada penelitian ini yaitu instrumen tes yang memenuhi beberapa ranah kognitif penguasaan konsep yaitu : mengingat (C1), memehami ( $\mathrm{C} 2$ ), mengaplikasikan (C3), menganalisis (C4). Bentuk tes yang digunakan berupa tes pilihan ganda yang terdiri dari 13 soal. Sebelum digunakan sebegai instrumen tes, soal soal tersebut telah di uji validitas dan reabilitasnya dan dinyatakan valid dan reable.
Analisis data dilakukan dengan uji hipotesis dengan menggunakan uji Independent Sample T Test pada program SPSS versi 16.00. Sebelum dilakukan uji hipotesis data terlebih dahulu di uji normalitas menggunakan shapiro wilk dan uji homogenitas menggunakan levene's tets. Pada penelitian juga dilakukan observasi aktifitas siswa pada kelas kontrol dan eksperimen dengan menggunakan lembar observasi dan bantuan dua orang pengamat.

\section{HASIL DAN PEMBAHASAN Hasil}

Data penguasaan konsep didapatkan dari hasil pretest dan posttest dari kelompok kelas kontrol dan kelas eksperimen. Deskripsi data penguasaan konsep siswa pada kelas kontrol dan eksperimen terlihat pada Tabel 2. Nilai rata- rata pretest kelas eksperimen sebesar 36,63 dan kelas kontrol sebesar 43,37 sedangkan nilai rata rata posttest kelas eksperimen sebesar 83,53 dan kelas kontrol sebesar 70,00. Dari data tersebut terlihat bahwa kelas eksperimen mengalami peningkatan yang lebih tinggi dibandingkan kelas kontrol.

Tabel 1. Deskripsi Data

\begin{tabular}{lccccc}
\hline \multicolumn{5}{c}{ Descriptive Statistics } \\
\hline & N & Min & Max & Mean & $\begin{array}{c}\text { Std. } \\
\text { Deviation }\end{array}$ \\
\hline preKOn & 30 & 20 & 67 & 43.37 & 12.853 \\
Poskon & 30 & 53 & 87 & 70.00 & 8.906 \\
preEks & 30 & 13 & 60 & 36.63 & 12.853 \\
PosEks & 30 & 67 & 100 & 83.53 & 9.551 \\
$\begin{array}{l}\text { Valid N } \\
\text { (listwise) }\end{array}$ & 30 & & & & \\
\hline
\end{tabular}

Hasil uji normalitas untuk semua kelas terlihat pada tabel 3. Uji normalitas pretest kelas kontrol didapatkan sebesar 0,20 dan kelas eksperimen sebesar 0,20. Sedangkan posttest kelas kontrol didapatkan sebesar 0,173 dan kelas eksperimen sebesar 0,112. Nilai tersebut menunjukkan nilai siginifikasi 
untuk semua kelas >0,05, hal tersebut berarti bahwa seluruh data baik kelas kontrol maupun eksperimen terdistribusi normal

Tabel 2. Ringkasan Uji Normalitas

\begin{tabular}{cccc}
\hline No & Kelompok & Sig & Kesimpulan \\
\hline 1 & $\begin{array}{c}\text { Pretest } \\
\text { Eksperimen } \\
2\end{array}$ & 0,200 & Normal \\
$\begin{array}{c}\text { Posttest } \\
\text { Eksperimen }\end{array}$ & 0,112 & Normal \\
3 & Pretest Kontrol & 0,200 & Normal \\
4 & Posttest Kontrol & 0,173 & Normal
\end{tabular}

Hasil uji homogenitas terlihat pada tabel 3. Signifikansi kelas kontrol didapatkan sebesar 1,626 dan kelas eksperimen sebesar 1,747 yang berarti data kedua kelas menunjukkan homogen.

Tabel 3. Ringkasan Uji Homogenitas

\begin{tabular}{ccc}
\hline Test & Sig & Keterangan \\
\hline Control & 1.626 & Homogen \\
Eksperimen & 1.747 & Homogen \\
\hline
\end{tabular}

Dengan terpenuhinya kedua syarat pada data yaitu terdistribusi normal dan homogen maka selanjutnya dilakukan uji Independent Sample T Test dan didapatkan hasil thitung sebesar 5.676 dengan signifikansi sebesar 0,000 seperti terlihat pada tabel 4 . Hasil perhitungan tersebut menunjukkan angka yang lebih besar dari tabel yang nilainya 0,000 . Dengan begitu dapat ditarik kesimpulan bahwa ada pengaruh yang signifikan penerapan model CTL berbantuan media ular tangga terhadap penguasaan konsep fisika siswa.

Berdasarkan analisis N-Gain didapatkan hasil rata-rata nilai kelas kontrol sebesar sebesar 0.45 dan kelas eksperimen sebesar 0.75 seperti pada tabel 5. Hal tersebut berarti bahwa peningkatan penguasaan konsep siswa kelas eksperimen termasuk kategori tinggi. Sedangkan pada kelas kontrol besarnya peningkatan penguasaan konsep siswa termasuk kategori sedang.

Tabel 4. Hasil uji t

\begin{tabular}{|c|c|c|c|c|c|c|c|c|}
\hline \multicolumn{9}{|c|}{ Independent Samples Test } \\
\hline $\begin{array}{r}\text { Leve } \\
\text { Test } \\
\text { Equa } \\
\text { of } \\
\text { Varia } \\
\end{array}$ & $\begin{array}{l}\text { ne's } \\
\text { for } \\
\text { lity } \\
\text { nces } \\
\end{array}$ & \multicolumn{7}{|c|}{ t-test for Equality of Means } \\
\hline $\mathbf{F}$ & Sig. & $\mathbf{t}$ & df & Sig. & $\begin{array}{c}\text { Mean } \\
\text { Differe } \\
\text { nce }\end{array}$ & $\begin{array}{c}\text { Std. } \\
\text { Error } \\
\text { Differe } \\
\text { nce }\end{array}$ & \begin{tabular}{|r}
9 \\
Confi \\
Interva \\
Diffe \\
Lower \\
\end{tabular} & $\begin{array}{l}5 \% \\
\text { idence } \\
\text { al of the } \\
\text { rence } \\
\text { Upper } \\
\end{array}$ \\
\hline \multirow[t]{2}{*}{.306} & .582 & -.209 & 58 & .835 & -.500 & 2.391 & $\begin{array}{c}- \\
5.286\end{array}$ & 4.286 \\
\hline & & -.209 & 57.7 & .835 & -.500 & 2.391 & $\begin{array}{c}- \\
5.286\end{array}$ & 4.286 \\
\hline
\end{tabular}

Tabel 5. Hasil Perhitungan N-Gain

\begin{tabular}{cccccc}
\hline \multicolumn{5}{c}{ hGroup Statistics } \\
\hline \multirow{4}{*}{ Ngain } & Variable & $\mathrm{N}$ & Mean & $\begin{array}{c}\text { Std. } \\
\text { Deviation }\end{array}$ & $\begin{array}{c}\text { Std. } \\
\text { Error } \\
\text { Mean }\end{array}$ \\
& & & & & .20001 \\
& Kontrol & 30 & .4504 & .03652 \\
& Eksperimen & 30 & .7514 & .12447 & .02273 \\
\hline
\end{tabular}

\section{Pembahasan}

Penguasaan konsep merupakan bagian dari salah satu hasil belajar. Penguasaan konsep penting dimiliki siswa sehingga tidak akan terjadi miskonsepsi materi dalam proses pembelajaran dan proses pembelajaran akan berjalan secara menarik karena siswa tidak hanya menghafal materi tetapi benar benar belajar suatu materi (Hidayat \& Syahidin, 2019).

Penguasaan konsep terkait erat dengan enam dimensi proses kogintif, Benjamin. S. Bloom, mengemukakan bahwa enam jenjang berpikir kognitif meliputi: mengingat (C1), memahami (C2), mengaplikasikan (C3), menganalisis (C4), mengevaluasi (C5) dan mencipta (C6) (Anderson \& Krathwohl, 2001). Mengingat merupakan proses mendapatkan kembali pengetahuan diri memori jangka panjang. Kateori mengingat yaitu memanggil kembali pengetahuan dari memori jangka panjang yang digunakan untuk membandingkan dengan informasi yang disajikan dan 
memanggil kembali pengetahuan yan relevan dari memori ketika hdiberi pertanyaan. Memahami merupakan memahami maksud dari pertanyaan baik komunikasi tulis, lisan dan grafik. Menerapkan merupakan mengunakan prosedur dalam masalah yang diberikan. Kategori menerapkan adalah melaksanakan yaitu menerapkan prosedur pada tugas yang berbeda pada tugas-tuggas sebelumnya; Menerapkan yaitu memilih dan mengunakan prosedur pada tugas yang tidak umum. Menganalisis merupakan memecahkan material menjadi baian-bagian pokok dan menentukan bagaimana setiap bagian dapat berhubunan satu sama lain dan pada struktur keseluruhan, kategori analisis meliputi membedakan yaitu memilih dan memilah bagian relefan dan tidak relefan dari material yang dipresentasikan; mengorganisasikan yaitu mengidentifikaskan bagian dari sebuah situasi kemudian menyusun kembali menjadi struktur yang koheren; menghubungkan yaitu menegaskan sudut padang, bias, nilai, atau maksud mendesar bahan yang dipresentasikan. Mengevaluasi merupakan pembuatan keputusan berdasarkan kateria dan standar. Kategori evaluasi meliputi mengecek yaitu mendeteksi ketidak konsistenan dalam sebuah proses atau produk mempunyai konsistensi internal, mendeteksi keefektifan prosedur yang digunakan; mengkritisi yaitu mendeteksi ketidak konsistenan antara produk dan kateria eksternal, menentukan apakah sebuah produk mempunyai konsistensi internal, mendeteksi dari prosedur dari masalah yang diberikan. Menciptakan merupakan mengorganisasikan kembali elemen ke pola baru. Kategori menciptakan meliputi membangkitkan yaitu memberikan alternatif hipotesis berdasarkan kriteria; merencanakan yaitu merancang prosedur untuk memenuhi beberapa tugas; memproduksi yaitu membuat produk (Hermansyah et al., 2015; Ramdani et al., 2020).

Jadi siswa dikatakan telah menguasai konsep apabila setelah proses pembelajaran mampu mengingat, memahami atau mengerti apa yang dikerjakan, menggetahui apa yang sedang dikomunikasikan, memberikan penjelasan atau memberi uraian yang lebih rinci denggan mengggunakan kata-kata sendiri, mampu memecahkan masalah yang dihadapinya, serta mampu mengaplikasikannya dalam kehidupan sehari-hari di linkungannya mupun di lingkungan masyarakat (Hafadoh, 2016; Manao, 2013; Mauke et al., 2013).

Namun di lapangan banyak siswa yang susah dalam memahami konsep khususnya untuk materi fisika. sebagai efeknya maka siswa berangapan fisika merupakan mata pelajaran yang isinya hanyalah rumus rumus. Kondisi ini harusnya tidak terjadi jika siswa memahami betul konsep materi yang sedang dipelajari. Untuk menghindari siswa tidak paham konsep maka dalam proses pembelajaran dibutuhkan inovasi seperti penggunaan model pembelajaran yang lebih menarik bagi siswa atau mempermudah siswa dalam memahami konsep. Salah satu model pembelajaran yang cocok yaitu model pembelajaran konstektual (Contextual Teaching Learning). CTL merupakan pembelajaran yang mengaitkan situasi dunia nyata dengan materi pembelajaran dapat membuat siswa lebih mudah dalam memahami materi (Berns \& Erickson, 2001). Siswa juga cenderung lebih tertarik dalam proses pembelajaran karena mereka merasa bahwa materi yang sedang mereka pelajari tidak abstrak. Model CTL sangat efektif diterapkan dalam proses pembelajaran fisika karena dapat melatih siswa untuk menemukan konsep lebih mudah (Yuwandra \& Arnawa, 2020), menciptakan suasana pembelajaran yang 
bermakna, pembelajaran yang lebih produktif dan mampu menumbuhkan penguatan konsep kepada siswa (Handini et al., 2016).

Bantuan media pembelajaran juga merupakan salahsatu inovasi pembelajaran yang dibutuhkan siswa. Penggunaan media ular tangga dalam model pembelajaran CTL terbukti mempengaruhi penguasaan konsep fisika secara signifikan. Siswa lebih mudah memahami konsep fisika saat model pembelajaran yang diterapkan di kelas menggunakan pendekatan konstektual dan dengan menggunakan bantuan media ular tangga. Hal tersebut juga selaras dengan hasil penelitian yang telah dilakukan oleh (Firman \& Maisyarah, 2019; Nugroho et al., 2013) yang menyatakan bahwa media pembelajaran fisika menggunakan permainan ular tangga dapat meningkatkan motivasi dan hasil belajar siswa.

\section{PENUTUP}

Model Contextual Teaching and Learning (CTL) berbantuan media ular tangga berpengaruh secara signifikan terhadap penguasaan konsep siswa. Sehingga penggunaan media permainan ular tangga disarankan untuk digunakan dalam proses pembelajaran.

\section{REFERENSI}

Anderson, L. W., \& Krathwohl, D. R. (2001). A taxonomy for learning, teaching, and assessing: A revision of Bloom's taxonomy of educational objectives. Longman,.

Berns, R., \& Erickson, P. (2001). Contextual Teaching and Learning: Preparing Students for the New Economy. The Highlight Zone Research, 5, 1-8.

Dewi, P. Y. A., \& Primayana, K. H. (2019). Effect of Learning Module with Setting Contextual Teaching and Learning to Increase the Understanding of Concepts. International Journal of
Education and Learning, 1(1). https://doi.org/10.31763/ijele.v1i1.26

Fadillah, A., Dewi, N. P. L. C., Ridho, D., Majid, A. N., \& Prastiwi, M. N. B. (2017). The effect of application of contextual teaching and learning (CTL) model-based on lesson study with mind mapping media to assess student learning outcomes on chemistry on colloid systems. International Journal of Science and Applied Science: Conference Series, 1(2). https://doi.org/10.20961/ijsascs.v1i2.5 128

Firman, F., \& Maisyarah, E. (2019). Media Permainan Ular Tangga, Motivasi Dan Hasil Belajar Peserta Didik Di Sekolah Dasar. Researchgate.Net. https://doi.org/10.31227/osf.io/46prn

Hafadoh, M. (2016). Pembelajaran CTL Menggunakan Model PBL Dalam Meningkatkan Penguasaan Konsep Dan Kemampuan Literasi Sains Siswa Smp. http://repository.upi.edu/id/eprint/2335 1

Handini, D., Gusrayani, D., Ilmiah, R. P.-J. P., \& 2016, U. (2016). Penerapan Model Contextual Teaching And Learning Meningkatkan Hasil Belajar Siswa Kelas Iv Pada Materi Gaya. Jurnal Pena Ilmiah, 1(1), 451-460. https://doi.org/10.23819/pi.v1i1.2974

Hapizoh, A., Jufrida, J., \& Darmaji, D. (2020). Penerapan Model Contextual Teaching And Learning Untuk Meningkatkan Motivasi Siswa Di Kelas Vii Smpn 30 Muaro Jambi. EduFisika, 5(01), 45-51. https://doi.org/10.22437/edufisika.v5i0 1.7296

Hermansyah, H., Gunawan, G., \& Herayanti, L. (2015). Pengaruh Penggunaan Laboratorium Virtual Terhadap Penguasaan Konsep dan Kemampuan Berpikir Kreatif Mahasiswa Pada Materi Getaran dan Gelombang. Jurnal Pendidikan Fisika Dan Teknologi, 1(2), 97-102. 
Hidayat, T., \& Syahidin, S. (2019). Inovasi Pembelajaran Pendidikan Agama Islam Melalui Model Contextual Teaching And Learning Dalam Meningkatkan Taraf Berfikir Peserta Didik. Jurnal Pendidikan Agama Islam, 16(2), 115136.

https://doi.org/10.14421/jpai.2019.162 $-01$

Huda, N., Hikmawati, H., \& Kosim, K. (2019). Pengaruh Pendekatan Kontekstual Berbantuan Alat Peraga Terhadap Penguasaan Konsep dan Kemampuan Pemecahan Masalah Fisika. Jurnal Pijar Mipa, 14(1), 62. https://doi.org/10.29303/jpm.v14i1.95 9

Husein, S., Herayanti, L., \& Gunawan, G. (2017). Pengaruh Penggunaan Multimedia Interaktif Terhadap Penguasaan Konsep dan Keterampilan Berpikir Kritis Siswa pada Materi Suhu dan Kalor. Jurnal Pendidikan Fisika Dan Teknologi, 1(3), 221. https://doi.org/10.29303/jpft.v1i3.262

Kamariyah, E. I., \& Budiyono, A. (2020). Pengaruh Model PBL (Problem Based Learning) terhadap Pemahaman Konsep dan Kesadaran Diri Siswa pada Pencemaran Lingkungan. Jurnal Pendidikan Fisika Dan Teknologi, 6(2). https://doi.org/10.29303/jpft.v6i2.2105

Lutvaidah, U. (2016). Pengaruh Metode dan Pendekatan Pembelajaran terhadap Penguasaan Konsep Matematika. Formatif: Jurnal Ilmiah Pendidikan MIPA, 5(3), 279-285. https://doi.org/10.30998/formatif.v5i3. 653

Manao, H. (2013). ... Pembelajaran Contextual Teaching and Learning (CTL) Terhadap Kemampuan Pemecahan Masalah dan Kemampuan Berpikir Kritis Matematik Siswa Sekolah http://digilib.unimed.ac.id/id/eprint/39 64

Mauke, M., Sadia, I. W., \& Suastra, I. W. (2013). Pengaruh Model Contextual
Teaching and Learning Terhadap Pemahaman Konsep dan Kemampuan Pemecahan Masalah dalam Pembelajaran IPA-Fisika di MTS Negeri Negara. E-Journal Program Pascasarjana Universitas Pendidikan Ganesha, 3(2). https://ejournalpasca.undiksha.ac.id/index.php/jurnal_ ipa/article/view/796

Nugroho, A., Raharjo, T., \& Wahyuningsih, D. (2013). Pengembangan Media Pembelajaran Fisika Menggunakan Permainan Ular Tangga Ditinjau Dari Motivasi Belajar Siswa Kelas VIII Materi Gaya. Jurnal Pendidikan Fisika, l(1), $11-18$. https://jurnal.fkip.uns.ac.id/index.php/ pfisika/article/view/1769

Permatasari, I., Jamzuri, J., \& Wahyuningsih, D. (2013). Penerapan Media Mind Mapping Programpada Model Pembelajaran Contextual Teaching And Learning (Ctl) Untuk Meningkatkan Motivasi Dan Hasil Belajar Fisika Pada Siswa Kelas XI.A2 SMA Negeri 4 Surakarta. Jurnal Pendidikan Fisika Universitas Sebelas Maret, $\quad 1(2), \quad 120238$. https://jurnal.fkip.uns.ac.id/index.php/ pfisika/article/view/2799

Puryadi, P., Rahayu, S., \& Sutrio, S. (2018). Pengaruh Model Pembelajaran Direct Instruction Berbantuan Bahan Ajar Berbasis Kontekstual Terhadap Hasil Belajar IPA Terapan Siswa Kelas X SMKN 4 Mataram Tahun Ajaran 2015/2016. Jurnal Pendidikan Fisika Dan Teknologi, 4(1), 23-32.

Rahmawati, T. D., Wahyuningsih, W., \& Dua Getan, M. A. (2019). Pengaruh Model Pembelajaran Contextual Teaching And Learning Terhadap Hasil Belajar Matematika Siswa. JINoP (Jurnal Inovasi Pembelajaran), 5(1). https://doi.org/10.22219/jinop.v5i1.80 21

Ramdani, A., Jufri, A. W., Jamaluddin, J., \& Setiadi, D. (2020). Kemampuan Berpikir Kritis dan Penguasaan Konsep 
Dasar IPA Peserta Didik. Jurnal

https://doi.org/10.29303/jppipa.v6i1.3

88

Ratnasari, S. F., \& Saefudin, A. A. (2018).

Efektivitas Pendekatan Contextual Teaching And Learning (CTL) Ditinjau Dari Kemampuan Komunikasi Matematika Siswa. MaPan, 6(1), 119127. https://doi.org/10.24252/mapan.2018v 6n1a11

Silaban, B. (2014). Hubungan antara penguasaan konsep fisika dan kreativitas dengan kemampuan memecahkan masalah pada materi pokok listrik statis. Jurnal Penelitian Bidang Pendidikan, 20(1), 65-75.

Sumarni, S., Kosim, K., \& Verawati, N. N. S. P. (2020). Pengaruh Model Pembelajaran Inkuiri Terbimbing Berbantuan Simulasi Virtual Terhadap Penguasaan Konsep Fisika Peserta Didik SMA. Jurnal Pendidikan Fisika Dan Teknologi, 6(2). https://doi.org/10.29303/jpft.v6i2.2042

Suprianto, S., Kholida, S. I., \& Andi, H. J. (2016). Pengaruh Pendekatan Contextual Teaching And Learning (Ctl) Berbantuan Media Powerpoint Terhadap Peningkatan Hasil Belajar IPA Fisika. Jurnal Penelitian Dan Pembelajaran IPA, 2(2). https://doi.org/10.30870/jppi.v2i2.427

Yulia, P., \& Ningsih, S. U. (2018). Pengaruh Penerapan Model Pembelajaran Probing Prompting dan Contextual Teaching and Learning Terhadap Hasil Belajar Ditinjau dari Motivasi Belajar Siswa Sekolah Menengah Kejuruan. Edumatika: Jurnal Riset Pendidikan Matematika, $\quad 1(1), \quad 56$. https://doi.org/10.32939/ejrpm.v1i1.21 8

Yuwandra, R., \& Arnawa, I. M. (2020). Development of learning tools based on contextual teaching and learning in fifth grade of primary schools. Journal of Physics: Conference Series, 1554(1). 